\title{
Insect Hybridization and Climate Change
}

\author{
Erica L. Larson ${ }^{1 * \dagger}$, Robin M. Tinghitella ${ }^{1 \dagger}$ and Scott A. Taylor ${ }^{2 \dagger}$ \\ ${ }^{1}$ Department of Biological Sciences, University of Denver, Denver, CO, United States, ${ }^{2}$ Department of Ecology and Evolution, \\ University of Colorado Boulder, Boulder, CO, United States
}

OPEN ACCESS

Edited by:

Lora A. Richards,

University of Nevada, Reno,

United States

Reviewed by:

Clement Fisher Kent

York University, Canada

Josh Jahner,

University of Nevada, Reno,

United States

*Correspondence:

Erica L. Larson

erica.larson@du.edu

TORCID:

Erica L. Larson

orcid.org/0000-0003-3006-645X

Robin M. Tinghitella

orcid.org/0000-0002-0049-5539

Scott A. Taylor

orcid.org/0000-0001-9580-9125

Specialty section:

This article was submitted to

Population and Evolutionary

Dynamics,

a section of the journal

Frontiers in Ecology and Evolution

Received: 24 April 2019

Accepted: 02 September 2019

Published: 20 September 2019

Citation:

Larson EL, Tinghitella RM and Taylor SA (2019) Insect Hybridization and Climate Change.

Front. Ecol. Evol. 7:348.

doi: $10.3389 /$ fevo.2019.00348
Contemporary global change is altering ecosystems at an unprecedented pace and scale. This critical period is a crisis for biodiversity, but the perturbations caused by global environmental change also offer new opportunities to study the evolution of species boundaries - their persistence, formation, or collapse-over rapid evolutionary timescales. Increasing temperature means and fluctuations have the potential to alter gene flow between species through changes in species distributions, interactions, life history, and temperature-dependent behavior. This is particularly true for insects, whose geographic ranges, behaviors, and life history traits are temperature dependent. Here, we review the potential for climate change to influence gene flow and species boundaries between closely related insect species. We focus on studies that have tracked changes in climate and insect distributions and/or have evaluated temperature dependent reproductive barriers between species.

Keywords: speciation, hybrid zones, temporal isolation, range expansions, mate choice

"It is the mode of life as a whole that is challenged by the environment"

-(Masaki, 1961)

Our understanding of the nature of species boundaries-the delineation of species through reproductive barriers-comes largely from studies of range expansions and secondary contact during the Quaternary ice ages ( 2.4 Mya, Hewitt, 2011; Canestrelli et al., 2016). The hybrid zones formed by these range expansions are windows on evolutionary process, places where we can link phenotypes that maintain species boundaries with their underlying genotype and the processes that drove their divergence (Hewitt, 1988; Harrison, 1990). Contemporary global change is altering species' habitat at an unprecedented pace and scale. This critical period is a crisis for biodiversity (Dirzo et al., 2014; Wiens, 2016), including insects (Sánchez-Bayo and Wyckhuys, 2019). These perturbations also offer a new opportunity to study the evolution of species boundaries-their persistence, formation, or collapse-over rapid evolutionary timescales (Brennan et al., 2015; Taylor et al., 2015; Grabenstein and Taylor, 2018).

Geographic variation within species is key to understanding at what level and how consistently species boundaries will respond to climate change (Rowe et al., 2014). Although we often think of "species interactions" as constants, they clearly vary, because species themselves are variable, as are the environmental contexts of their interactions (Harrison, 1985; Larson et al., 2014; Mandeville et al., 2015, 2017). If species are adapted to local climate, then they will respond differently to climate change across their range. This is true for all aspects of climate change (e.g., temperature, humidity, and precipitation), but in particular, latitudinal variation in temperature is changing rapidly and can play a significant role in reproductive timing and behavior in many organisms (Senner et al., 2017). 
Temperature changes may differentially affect reproduction and life-history traits of populations at different latitudes and/or elevations (Cohen et al., 2018), leading to varied consequences for populations occupying different regions of geographically expansive ranges. For example, populations at lower latitudes may have narrower thermal tolerances and be more affected by changing temperatures (Janzen, 1967; Addo-Bediako et al., 2000).

Insects may be particularly susceptible to anthropogenic temperature change because their ranges, life history traits (e.g., lifecycle, development time), and behaviors (e.g., song) are often temperature dependent (Tauber and Tauber, 1981; Masaki, 1983; Doherty, 1985). Increasing temperature means and fluctuations have the potential to alter gene flow between insect species through changes in distributions, interactions, life history, and temperature-dependent behavior. Here we review the potential for climate change to influence gene flow and species boundaries between insect species. We focus on studies that have tracked changes in climate and insect distributions and/or have evaluated temperature dependent reproductive barriers between species. Our goal is to highlight the exciting field-based experiments that are possible as insects respond to changing climate, and the opportunities to understand the origin and maintenance of biodiversity in insect hybrid zones.

\section{SEASONAL LIFE CYCLE VARIATION IN INSECTS}

Seasonality shapes nearly all aspects of an insect's life history. Development, activity, and reproduction are all synchronized to seasonal fluctuations in light, temperature, moisture, and resource availability (Masaki, 1961; Tauber and Tauber, 1981). Often, insects withstand seasonal extremes via diapause-a period of low metabolic activity and developmental arrest triggered by daylight and/or temperature. In species with large ranges, seasonal adaptation is complicated by latitudinal and elevational transitions in season length, temperature and photoperiod (i.e., changes in day length). For some insects, diapause is obligatory and the developmental timing of diapause is fixed throughout their range (e.g., Berner et al., 2004). Other insects can respond to the length of the growing season by changing the onset (initiation) and close (termination) of diapause (e.g., Dingle et al., 1990; Dingle and Mousseau, 1994). In some cases, changes in the timing and duration of diapause determines the number of generations per year (voltinism). Across the range of a single species, populations can shift from one generation at higher latitudes or elevations to two or more generations per year at lower latitudes or elevations (including non-diapausing populations) (Levy et al., 2014). In the extreme, diapausing twice in a single life cycle is common in northern or high elevation species, likely because insects in these habitats need two seasons to complete development (Pickford, 1953).

To accommodate shifts in the length of growing season or the number of generations per year, some insects can adjust their rate of development. This appears to be more common in insects with long development times relative to the growing season (i.e., species with many nymphal stages, see Kivelä

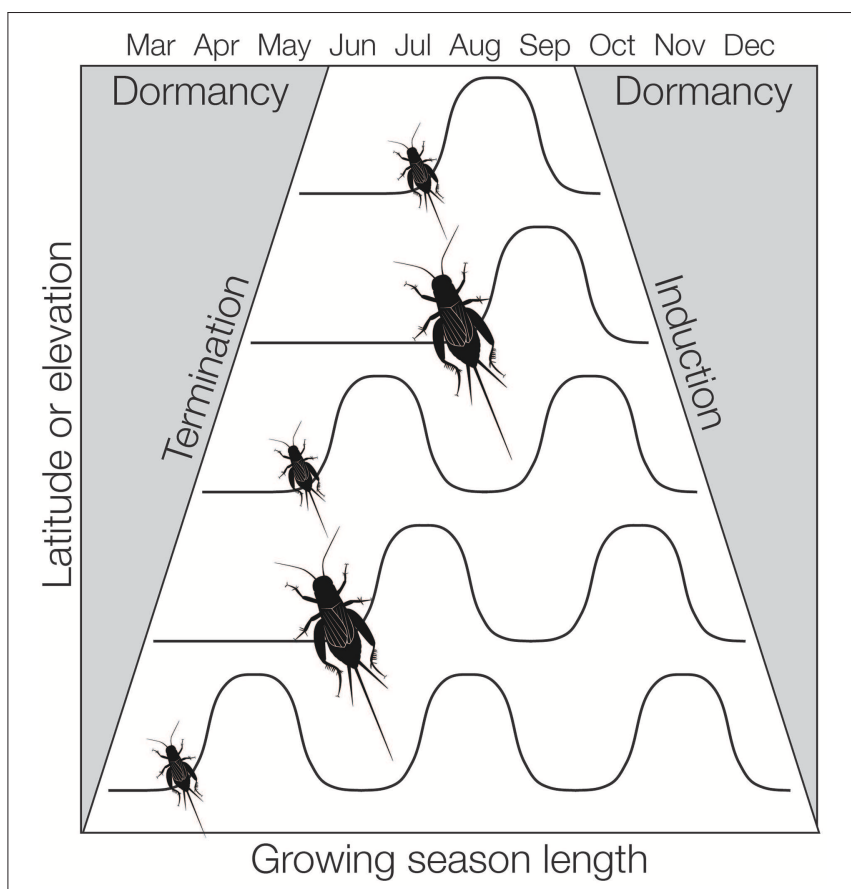

FIGURE 1 | How season length can affect the number of generations per year (voltinism) and body size in insects. As latitude or elevation increases, changes in the termination and initiation of diapause can shift to accommodate decreasing season length. Likewise, insects may develop faster and/or reach smaller adult body sizes to accommodate shorter growing seasons. Body size can also decrease in the south as species accommodate more generations per year. This figure is modified from Levy et al. (2014).

et al., 2011). For instance, the Emma field cricket, Telogryllus emma, is distributed across Japan and develops more quickly in northern populations than in southern populations (Masaki, 1967). The rate of development may in turn affect body sizeshorter growing seasons can select for more rapid development and smaller body size (Parsons and Joern, 2013). In insects, this phenomenon has been called the Converse of Bergman's rule (Masaki, 1967; Mousseau, 1997). However, there is not a simple correlation between body size and latitude. As species shift from continuous development at lower latitudes they can transition to two generations a year (bivoltinism) before reaching one generation a year (univoltinism) at higher latitudes. Fitting two generations in per year in mid-latitudes may come at a cost to body size (Figure 1). As a result, insects often have a concomitant shifting distribution in body size and life cycle across latitudinal and elevational gradients, known as a "sawtooth" pattern (Masaki, 1978a).

The shift in seasonal phenologies in insects can be so striking that Masaki (1978b) proposed the term "climatic speciation" to explain the parapatric distributions of populations with differing seasonal phenologies across latitudes. Indeed, temporal isolation due to local seasonal adaptation has been documented in many species [Table 1, see also references in the very thorough review by Taylor and Friesen (2017)], though perhaps climatic speciation is not as widespread as Masaki envisioned. Species that are 
TABLE 1 | Examples of species or subspecies temporally isolated through seasonal phenology.

\begin{tabular}{|c|c|c|c|c|c|}
\hline Species/subspecies & Common name & $\begin{array}{l}\text { Estimated } \\
\text { divergence }\end{array}$ & $\begin{array}{l}\text { Nature of temporal } \\
\text { isolation }\end{array}$ & $\begin{array}{l}\text { Evidence of moving hybrid zone, } \\
\text { range expansion or host shift? }\end{array}$ & References \\
\hline $\begin{array}{l}\text { Allonemobius socius } \\
\text { and } A \text {. fasciatus }\end{array}$ & Ground crickets & 6,000-60,000 уа & $\begin{array}{l}\text { Latitudinal variation in } \\
\text { voltinism }\end{array}$ & Hybrid zone is moving northwards & $\begin{array}{l}\text { Howard, 1986; Tanaka, } \\
\text { 1991; Britch et al., } \\
2001\end{array}$ \\
\hline $\begin{array}{l}\text { Gryllus firmus and } \\
\text { G. pennsylvanicus }\end{array}$ & Field crickets & 200,000 ya & $\begin{array}{l}\text { Time in egg to adult } \\
\text { development, latitudinal } \\
\text { variation in G. firmus } \\
\text { development time }\end{array}$ & $\begin{array}{l}\text { Hybrid zone may be expanding, but } \\
\text { possible correlations with climate } \\
\text { have not been studied }\end{array}$ & $\begin{array}{l}\text { Harrison, 1985; Larson } \\
\text { et al., } 2013\end{array}$ \\
\hline $\begin{array}{l}\text { Inurois punctigera early } \\
\text { and late-winter adults }\end{array}$ & $\begin{array}{l}\text { Japanese winter } \\
\text { geometrid moths }\end{array}$ & $\begin{array}{l}\text { Mean F } 0.382 \\
(\text { mtDNA), } 0.027 \\
(\text { AFLP)a }\end{array}$ & Seasonal adult emergence & $\begin{array}{l}\text { Dispersal to harsher winter climates is } \\
\text { predicted to lead to repeated shifts to } \\
\text { early and later winter adults. }\end{array}$ & $\begin{array}{l}\text { Yamamoto and Sota, } \\
\text { 2009, } 2012\end{array}$ \\
\hline $\begin{array}{l}\text { Magicicada spp. } 17 \text { - } \\
\text { and 13-year life cycles }\end{array}$ & Periodical cicadas & $\geq 0.5$ Mya & $\begin{array}{l}\text { Seasonal adult emergence. } \\
\text { Species are isolated by } \\
\text { differing life cycles as well as } \\
\text { broods that emerge in } \\
\text { different years. }\end{array}$ & $\begin{array}{l}\text { Life cycle switching is believed to be } \\
\text { due to selection pressure from } \\
\text { changing climate. }\end{array}$ & $\begin{array}{l}\text { Marshall and Cooley, } \\
\text { 2000; Simon et al., } \\
\text { 2000; Cooley et al., } \\
\text { 2001; Sota et al., 2013; } \\
\text { Koyama et al., } 2016\end{array}$ \\
\hline $\begin{array}{l}\text { Melanoplus devastator } \\
\text { and } M \text {. sanguinipes }\end{array}$ & Grasshoppers & Mean F $_{\mathrm{ST}} 0.5$ & $\begin{array}{l}\text { Development time and } \\
\text { reproductive diapause }\end{array}$ & & Orr, 1996 \\
\hline $\begin{array}{l}\text { Neophasia menapia } \\
\text { Early and late adults }\end{array}$ & Pine white butterfly & $\begin{array}{l}\text { GST } 0.057 \text { (goat } \\
\text { mountain), } 0.031 \\
\text { (mendocino }^{b} \\
\text { pass) }\end{array}$ & Seasonal adult emergence & & Bell et al., 2017 \\
\hline $\begin{array}{l}\text { Ostrinia nubilalis } \\
\text { E and Z } \\
\text { pheromone strains }\end{array}$ & $\begin{array}{l}\text { European corn } \\
\text { borer moth }\end{array}$ & $\mathrm{F}_{\mathrm{ST}}=0.05$ & $\begin{array}{l}\text { Latitudinal variation in } \\
\text { voltinism }\end{array}$ & $\begin{array}{l}\text { Introduced in early 20th century, } \\
\text { subsequent range expansion }\end{array}$ & $\begin{array}{l}\text { Dopman et al., 2010; } \\
\text { Dopman, 2011; Levy } \\
\text { et al., 2014; Kozak } \\
\text { et al., } 2017\end{array}$ \\
\hline $\begin{array}{l}\text { Papilio glaucus and } \\
\text { P. canadensis }\end{array}$ & $\begin{array}{l}\text { Swallowtail } \\
\text { butterflies }\end{array}$ & 0.5-0.6 mya & $\begin{array}{l}\text { Seasonal adaptation } \\
\text { (diapause and growth) }\end{array}$ & & $\begin{array}{l}\text { Ording et al., 2010; } \\
\text { Scriber, 2011; Scriber } \\
\text { et al., 2014; Ryan } \\
\text { et al., } 2018\end{array}$ \\
\hline $\begin{array}{l}\text { Polyommatus agestis } \\
\text { and } P . \text { artaxeres }\end{array}$ & $\begin{array}{l}\text { Brown argus } \\
\text { butterfly }\end{array}$ & NA & $\begin{array}{l}\text { Latitudinal variation in } \\
\text { voltinism }\end{array}$ & $\begin{array}{l}\text { The southern species is expanding } \\
\text { northward, likely displacing the } \\
\text { northern species hybrid zone is } \\
\text { expanding }\end{array}$ & Mallet et al., 2010 \\
\hline $\begin{array}{l}\text { Rhagoletis pomonella } \\
\text { apple and haw races }\end{array}$ & Apple maggot fly & $\sim 160$ yа & $\begin{array}{l}\text { Seasonal adult emergence, } \\
\text { corresponding to host } \\
\text { phenology }\end{array}$ & & $\begin{array}{l}\text { Feder and Filchak, } \\
\text { 1999; Filchak et al., } \\
2000 ; \text { Ragland et al., } \\
2012\end{array}$ \\
\hline $\begin{array}{l}\text { Thaumetopoea } \\
\text { pityocampa winter and } \\
\text { summer larval strains }\end{array}$ & $\begin{array}{l}\text { Pine processionary } \\
\text { moth }\end{array}$ & 560 generations & Seasonal diapause timing & $\begin{array}{l}\text { The southern summer strain initially } \\
\text { spread along the Portugal coast, but } \\
\text { species distribution models predicted } \\
\text { that the summer strain range will } \\
\text { decrease with climate change. }\end{array}$ & $\begin{array}{l}\text { Pimentel et al., 2006; } \\
\text { Santos et al., 2007, } \\
\text { 2011; Burban et al., } \\
\text { 2016; Godefroid et al., } \\
\text { 2016; Leblois et al., } \\
2017\end{array}$ \\
\hline
\end{tabular}

${ }^{a}$ Calculated from Yamamoto and Sota (2012).

${ }^{b} G_{S T}$ between early and late flight adults within a site were similar to $G_{S T}$ between geographically isolated populations.

distributed across large latitudinal or elevational gradients often have different seasonal lifecycles, but still maintain sufficient gene flow to be considered a single species (Amari et al., 2018). However, climate change may dramatically alter interactions among species or parapatrically distributed populations. For species to persist in the face of climate change, populations must synchronize their phenology with the environmental conditions and with other interacting populations (Senner et al., 2017).

Insects are responding to climate change by altering the seasonal timing of adult emergence (Diamond et al., 2011; Maurer et al., 2018). For example, over the past 50 years,
Rocky Mountain grasshoppers at high elevation have delayed development, while low elevation populations have advanced development (Buckley et al., 2015). Insects are also responding by increasing the number of generations they have per year (Tobin et al., 2008; Altermatt, 2010). Even the simplest changes in insect life cycles can affect temporal isolation between sympatric taxa (Taylor and Friesen, 2017). Species may adjust the timing of diapause or the number of generations per year so that reproductive activity among populations or species are no longer synchronized (Santos et al., 2007, 2011) or there is less temporal isolation between closely related species (Dopman et al., 


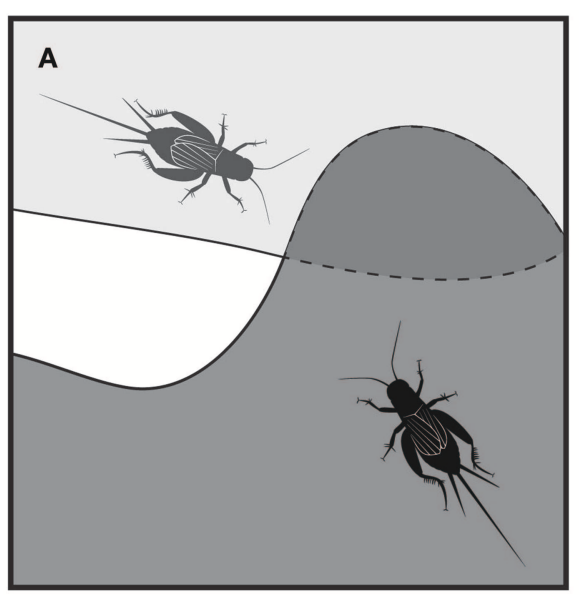

increased contact

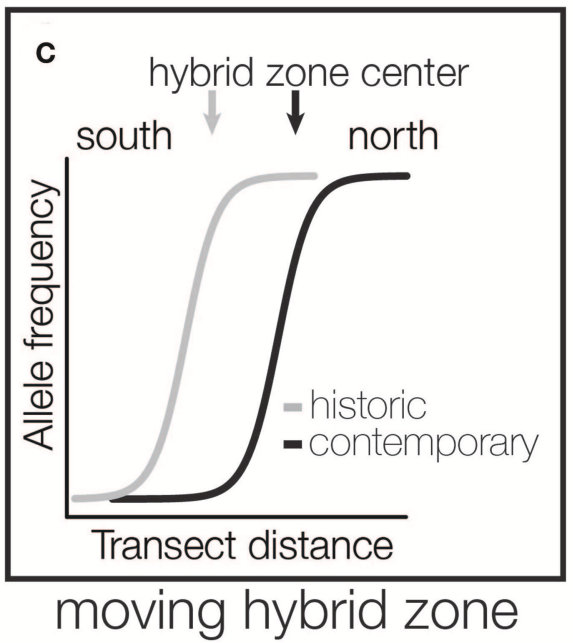

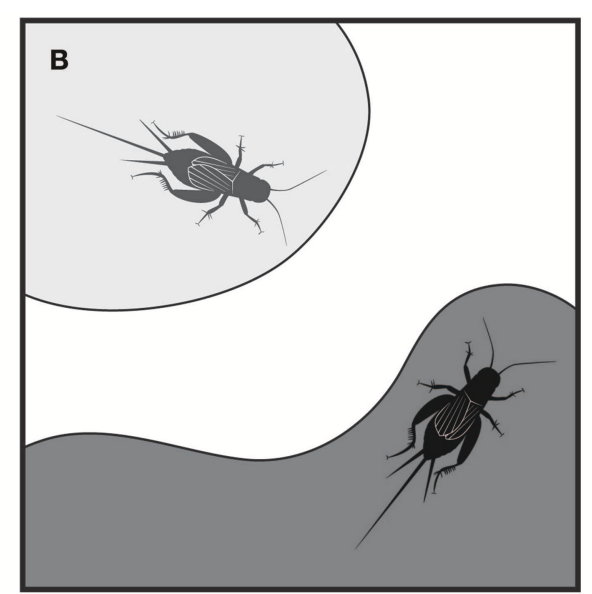

decreased contact

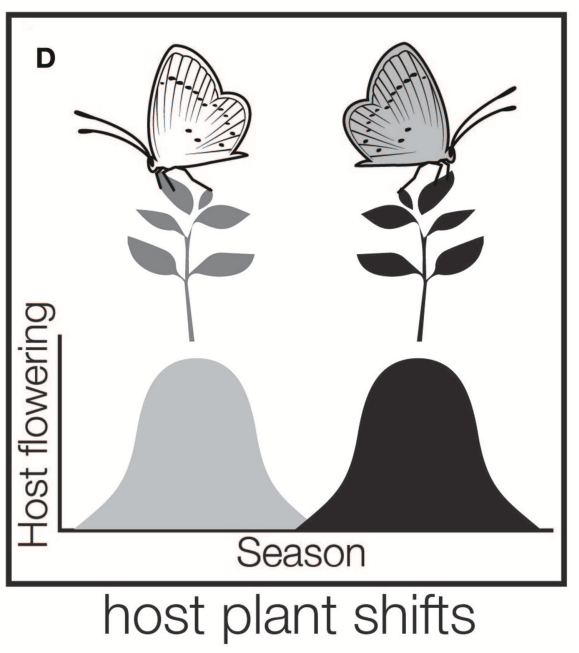

FIGURE 2 | Possible outcomes of insect range changes on the potential for hybridization. As insect ranges change due to climate, we can expect that some species that were previously allopatric will have new areas of contact (A). Likewise, ranges may shrink for some species or populations, potentially decreasing hybridization or gene flow (B). Species that already interact in hybrid zones may experience new species interactions (e.g., changing species densities, new environmental contexts) as hybrid zones shift with changing species ranges (C). As species occupy new habitat, there is the potential for herbivorous insects to shift to new host species, leading to increased or decreased contact with other species (D).

2010). Shifts in the timing of adult emergence will change the context of species interactions: reproductive barriers may collapse, or climate change could lead to losses of population connectivity (Grabenstein and Taylor, 2018). Although we have focused on temperature, all aspects of climate change will affect insect seasonal phenology, particularly precipitation (which also influences diapause timing). Changes in seasonal life cycle are also intimately tied with changes in species distributions and host plant shifts.

\section{RANGE EXPANSIONS WITH CHANGING CLIMATE}

As global climate rapidly changes, insects are modifying their distributions. Using historic and contemporary surveys, coupled with climate data, studies have documented both northward and elevational range expansions (Parmesan et al., 1999; Nufio et al., 2010; Breed et al., 2013; Menéndez et al., 2013; Ryan et al., 2018) or changes to insect migration routes (Sparks et al., 2007). So far, we lack the ability to predict which species will undergo range expansions, which appears to be species dependent (Hellmann et al., 2008; Menéndez et al., 2013). However, it is clear that species' responses to climate change are leading to new (Wellenreuther et al., 2010) or shifting (Ryan et al., 2018) overlap between species (Figure 2A). Climate change will also lead to range contractions (Merrill et al., 2008), and the greater potential for loss of population connectivity and isolation (Figure 2B).

Beyond the generation of new regions of hybridization, species that currently interact in hybrid zones may experience changing species interactions as hybrid zones move in response to climate 
change (Figure 2C). While hybrid zone movement is likely common (Buggs, 2007), and in fact expected for hybrid zones that are associated with environmental factors [e.g., mosaic hybrid zones (Harrison, 1986), clinal hybrid zones (Endler, 1977)], there are few long term studies of shifts in insect hybrid zones, and fewer still that link movement to environmental variation (Dasmahapatra et al., 2002). As a result, how modified species interactions in insect hybrid zones might be altered by climate change generally remains unclear. Still, moving hybrid zones are excellent opportunities to study the nature of species interactions and a concerted effort should be made to detect moving hybrid zones and consistently sample them through time. The few longterm studies of moving insect hybrid zones have provided some of our most robust observations of climate-related introgression: more discoveries will be made if we pay closer attention to moving insect hybrid zones.

For example, the Michigan portion of the hybrid zone between two North American tiger swallowtail butterflies in the genus Papilio (P. glaucus and P. canadensis) has shifted northward in response to climate change over the last $\sim 30$ years (Scriber, 2011; Scriber et al., 2014; Ryan et al., 2018). By tracking the hybrid zone through time, Scriber and colleagues have learned much about interspecific gene flow, ecological divergence, incipient speciation, and hybrid zone movement. Importantly, researchers have been able to document introgression of species-specific alleles in response to climate change. This includes alleles related to the ability of Papilio larvae to detoxify host plants, which have introgressed northwards $200 \mathrm{~km}$ over the past 15 years due to strong selection on novel detoxification phenotypes produced within the hybrid zone (Scriber, 2011; Scriber et al., 2014). Alleles related to diapause control have also introgressed northwards in the Papillo hybrid zone, highlighting how range expansions can correspond to changes in seasonal phenologies (Crozier and Dwyer, 2006).

The link between range expansions and seasonal adaptation is not always intuitive. The mosaic hybrid zone between the ground crickets Allonemobius fasciatus (northern species) and A. socius (Howard and Waring, 1991) was shown to have shifted northward over a 14-year period (Britch et al., 2001). This shift is due, at least in part, to year to year variation in population growth rate of either species. Hybrid zones are often at the edge of a species' range, so even slight perturbations to the environment may have a major impact on the relative fitness of parental species or hybrids where populations overlap. However, the northward expansion of $A$. socius may be constrained by the $A$. socius bivoltine lifecycle (Fedorka et al., 2012). Moving hybrid zones are a complex interaction between population level dynamics, and the potential for local adaptation (i.e., standing genetic variation or phenotypic plasticity).

Both the Papillo and Allonemobius hybrid zones have been studied extensively in one region of a fairly large area of contact. The geographic consistency of the patterns that have been documented is unknown. Replicating these studies across different areas of contact will give us greater insight into how local adaptation and population structure influence changing species contact zones. In general, we should aim to study geographically expansive hybrid zones that can provide new insight into the consistency of reproductive barriers across different climatic gradients (see section "Ways Forward").

\section{INTERACTIONS BETWEEN SEASONALITY AND HOST PLANT SHIFTS}

Climate change is predicted to alter herbivorous insect and host plant interactions. The availability and quality of host plants can be altered by changing temperatures and precipitation. Host plant populations may decline, forcing insects to shift to novel hosts (Parmesan, 2006), or the stress of increasing temperatures and drought may expose plants to novel pests, facilitating the spread of some herbivores (Jamieson et al., 2012). Changing seasonal phenologies for insects or their hosts can cause insects to become desynchronized with their host plant, possibly forcing them on to a new host. Host plant shifts (and associated range expansions) can lead to increased or decreased contact between species or involve changes in seasonality (Forbes et al., 2017; Figure 2D). An excellent example of this is the apple maggot fly, Rhagoletis pomonella, which underwent a host shift from North American native hawthorn fruit to introduced apple trees in the 1860s (Bush, 1969). Apple host races of $R$. pomonella have advanced their adult emergence by $\sim 3$ weeks to accommodate the earlier availability of apple fruit, causing temporal isolation between apple and hawthorn host races (Feder and Filchak, 1999; Filchak et al., 2000). This means that apple host races enter diapause earlier in the fall while temperatures are still relatively warm. Metabolic rates in insects increase with external temperature, even during diapause, and the apple host races must maintain higher energy stores to survive longer pre-winter diapause (Ragland et al., 2012). The shift from haw to apple may have been preceded by prior host shifts in the $R$. pomonella species complex, secondary contact, and gene flow among allopatric populations as $R$. pomonella species expanded their ranges from isolated southern populations in the US and Mexico ( $\sim 1.5$ mya). As $R$. pomonella species moved north, the timing of their diapause likely shifting with increasing latitudes and novel host species (e.g., snowberries, blueberries, sparkleberries, flowering dogwood, and finally apple; Feder et al., 2003, 2005; Xie et al., 2008; Mattsson et al., 2015).

\section{COUPLING AND MISMATCH OF SIGNALS AND CHOOSER PREFERENCES}

Global climate change poses largely unknown threats to insect reproduction (Dell et al., 2011; Narins and Meenderink, 2014; Gibert et al., 2016). Individuals mate within critical temperature ranges, and the signals that some insects use to communicate are thermally sensitive (Dolbear, 1897; Edmunds, 1963; Doherty, 1985; Pires and Hoy, 1992; Conrad et al., 2017). Acoustic communication is the primary sexual signal for many insects and insect songs can be used in longdistance mate location, courtship, and male-male competition contexts. Several characteristics of songs (e.g., frequency, pulse length, interpulse length), but most notably, the pulse rate, are temperature-dependent; the pulse rate of cricket 
songs, for instance, quite famously increases linearly with temperature in multiple species (Walker, 1962; Walker and Cade, 2003). The temperature-dependent aspects of signals are often the very traits that are used to identify appropriate mates (Beckers and Schul, 2008).

Sexual signals are typically coupled with chooser (often females) preferences for those signals within species, ensuring that males attract conspecific females and females respond to conspecific males. Temperature coupling in reproductive traits (correspondence between changes in male signals and female preferences with temperature) has been demonstrated in several insects in response to temperatures experienced during development (Grace and Shaw, 2004) or as adults (Doherty and Hoy, 1985; Pires and Hoy, 1992). But, signal-preference mismatches are likely to stem from climate change because chooser preferences are not consistently thermally sensitive (Greenfield and Medlock, 2007; Deutsch et al., 2008). For instance, the mean carrier frequency of the courtship songs of Drosophila montana is temperature-dependent, but there is no temperature coupling of female preferences for carrier frequency (Ritchie et al., 2001). If the increased mean temperatures and temperature fluctuations characteristic of climate change shift male signals but not female preferences, or signals and preferences shift in different ways or to different degrees, we may find signal-preference mismatches with a variety of reproductive consequences (Figure 3). These consequences include mating with other species if altered temperatures increase the overlap between female preferences and heterospecific signals (Jang and Gerhardt, 2006) by changing characteristics of preference functions like peak preference, strength of preference, or tolerance (sensu Rodríguez et al., 2012). Increased temperatures may also reduce females' threshold for mating, increasing the frequency of mating and perhaps the likelihood of mismating (Kindle et al., 2006).

Cricket songs provide a concrete example. Divergence in song and mate preferences has played a key role in diversification of crickets (Otte, 1992; Mendelson and Shaw, 2005). Cricket songs consist of repeated pulses of sound organized into groups of chirps or trills. Males produce a conspicuous longdistance calling song to attract females from afar and, once in close proximity, switch to a lower intensity courtship song that is required before females will mount to receive the sperm-containing packet. Female crickets show the strongest preferences for temporal features of the calling and courtship songs (Gabel et al., 2016), and both songs contribute to precopulatory isolation between species (Fitzpatrick and Gray, 2001; Jang and Gerhardt, 2006; Maroja et al., 2014; Gray et al., 2016; Hennig et al., 2016). Closely related Hawaiian swordtail crickets (Laupala sp.), for instance, are ecologically and morphologically indistinguishable, but differ primarily in the pulse rate of their courtship song, which is thought to be reproductively isolating (Mendelson and Shaw, 2002, 2005). If increased temperatures shift female preferences directionally so that they encompass pulse rate characteristics of closely related species that co-occur geographically, we should find a signalpreference mismatch within species and increased mismating between species (Figure 3).
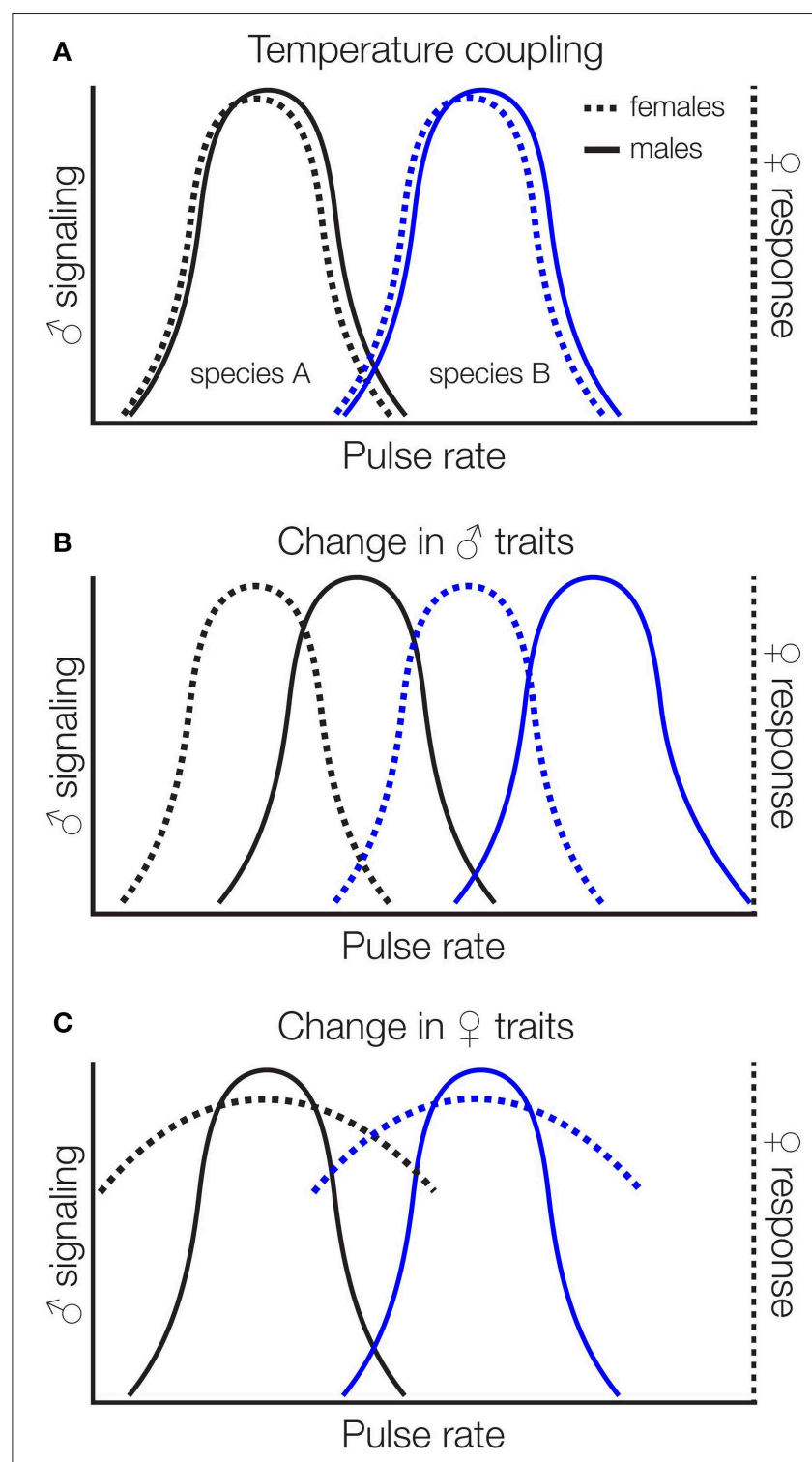

FIGURE 3 | Potential impacts of climate change on temperature dependent signals and preferences. Signals and chooser preferences are typically coupled (A). If increased mean temperatures, for instance, shift signals but not chooser preferences (B), or chooser preferences but not signals (C), or signals and preferences shift differentially (not shown), we might expect mismatches that lead to heterospecific mating. In (C) we show one possible shift in chooser preferences (more "relaxed" preference functions with high relative chooser responsiveness that encompasses more signal values), but shifts in peak preference and other characteristics are also possible.

Finally, behavioral ecologists have recently emphasized the importance of distinguishing between choosers' preferences and the mating decisions they make (Rosenthal, 2017). Preferences are not always reflected in mating decisions, and both are environmentally dependent. Even in the absence of changes in preference functions (the response of choosers to variation in signalers traits), if shifts in climate alter individuals' motivation to mate, sexual receptivity, or choices (including through changes 
in species interactions and changes in range or climate described above), there will be consequences for gene flow and the boundaries between closely related insect species.

\section{WAYS FORWARD}

The long-term permanence of species boundaries in the face of rapid change has been difficult to study, in part because interactions between closely related species are not constants. We have highlighted ways that reproductive barriers between species can be temperature sensitive. Future studies should conduct manipulative experiments to determine the temperature dependence of reproductive traits such as development time, host plant associations, and sexual signals. We should expand our taxonomic framework for studying the impacts of climate change on species boundaries. Much of the existing work has focused on a few well-studied groups (e.g., Lepidoptera and Orthoptera, see Table 1), which are poor generalizations for the diversity of insects. Perhaps most importantly, we should account for variation within species and the environmental context of their interactions (Larson et al., 2014; Mandeville et al., 2017). We lack geographically comprehensive field-based studies that account for variation within species, ecological context, and environmental changes. To understand how species will respond to climate change, we need to study geographic variation in the maintenance of species boundaries. This will involve studying species interactions across broad latitudinal or elevation transects. Patterns across these scales will be complicated by abiotic gradients, such as temperature, but also diet, predators, parasites, and competitors will determine the nature of species interactions (Masaki, 1961). The hardest aspect may simply be sampling populations across large continental scales.

Natural history collections are an obvious way forward for documenting changes in insect phenology and ranges (Kharouba et al., 2019). Collections provide a record of the recent past (Holmes et al., 2016), and can be a baseline for tracking insect's changing phenologies and geographic locations. Natural history collections have been successfully used to pinpoint the past timing of adult emergence (Nufio et al., 2010; Maurer et al., 2018), and to track changes in species ranges (Ryan et al., 2018). Collections and survey data (see citizen science data below) are limited to telling us that an event happened, but not the exact timing of the event in most cases. However, statistical methods can provide fairly accurate estimates of sparsely sampled populations (Pearse et al., 2017). Coupled with burgeoning methods for sequencing and analyzing historic DNA (Bi et al., 2013; Jones and Good, 2015; Ali et al., 2016), collections can be used to contrast historic and contemporary gene flow. Not only should we utilize natural history collections as much as possible,

\section{REFERENCES}

Addo-Bediako, A., Chown, S. L., and Gaston, K. J. (2000). Thermal tolerance, climatic variability and latitude. Proc. Biol. Sci. 267, 739-745. doi: $10.1098 / \mathrm{rspb} .2000 .1065$ but we should make a concerted effort to add to collections through specimens, photo documentation and preservation of quality tissue samples for genomic analyses. These collections are particularly important in hybrid zones, where temporal datasets will allow future scientists to directly observe the impacts of climate change on species boundaries (Taylor et al., 2015).

Much of what we know about the effects of climate change on insects are based on insect pests with long-term monitoring (Boggs, 2016). In the future we should expand the taxonomic diversity of climate change studies and use creative ways to collect data through citizen science projects with the public or in the classroom (Silvertown, 2009; Dickinson et al., 2012; Breed et al., 2013). Early citizen science projects often focused on charismatic vertebrates (e.g., eBird Sullivan et al., 2009), and initially the path forward for citizen science of less popular organisms, like insects, seemed less tractable. Now applications like iNaturalist, insect tracking websites (Berenbaum, 2012; Prudic et al., 2017), and public Bioblitzes are increasing natural history awareness and making citizen science data about insect distributions more accessible (Basset and Lamarre, 2019).

We are facing the devastating loss of uncharacterized biodiversity of insects (Habel et al., 2019; Sánchez-Bayo and Wyckhuys, 2019). While this is an unprecedented crises, these perturbations are also field-based experiments that provide an opportunity to understand the origin and maintenance of biodiversity (Taylor et al., 2015). Hybrid zones have provided many insights into the nature of species boundaries (Harrison and Larson, 2014; Gompert et al., 2017), but extant hybrid zones have formed and shifted over glacial scales. Climate change is an opportunity to understand how changing environments lead to new species, through the disruption of gene flow, the collapse of species through the breakdown of barriers, or the maintenance of species boundaries-all at a pace that is observable in our lifetime.

\section{AUTHOR CONTRIBUTIONS}

EL, RT, and ST contributed to the preparation of the manuscript.

\section{FUNDING}

RT and ST were supported by grants from the National Science Foundation (RT: IOS-1846520 and ST IOS-1754898).

\section{ACKNOWLEDGMENTS}

Discussions with Genevieve Kozak, Cesar Nufio, Kasey FowlerFinn, and Ryan Bracewell helped clarify our thinking, as did feedback from the University of Denver Ecology and Evolution group. 
Amari, H., Zebsa, R., Lazli, A., Bensouilah, S., Mellal, M. K., Mahdjoub, H., et al. (2018). Differential elevational cline in the phenology and demography of two temporally isolated populations of a damselfly: Not two but one taxon? Ecol. Entomol. 44, 93-104. doi: 10.1111/een.12680

Basset, Y., and Lamarre, G. P. A. (2019). Toward a world that values insects. Science 364, 1230-1231. doi: 10.1126/science.aaw7071

Beckers, O. M., and Schul, J. (2008). Developmental plasticity of mating calls enables acoustic communication in diverse environments. Proc. Biol. Sci. 275, 1243-1248. doi: 10.1098/rspb.2007.1765

Bell, K. L., Hamm, C. A., Shapiro, A. M., and Nice, C. C. (2017). Sympatric, temporally isolated populations of the pine white butterfly Neophasia menapia, are morphologically and genetically differentiated. PLOS ONE 12:e0176989. doi: 10.1371/journal.pone.0176989

Berenbaum, M. R. (2012). BeeSpotter at the University of Illinois. Am. Entomol. 58, 25-28. doi: 10.1093/ae/58.1.0025

Berner, D., Körner, C., and Blanckenhorn, W. U. (2004). Grasshopper populations across $2000 \mathrm{~m}$ of altitude: is there life history adaptation? Ecography 27, 733-740. doi: 10.1111/j.0906-7590.2005.04012.x

Bi, K., Linderoth, T., Vanderpool, D., Good, J. M., Nielsen, R., and Moritz, C. (2013). Unlocking the vault: next-generation museum population genomics. Mol. Ecol. 22, 6018-6032. doi: 10.1111/mec.12516

Boggs, C. L. (2016). The fingerprints of global climate change on insect populations. Curr. Opin. Insect Sci. 17, 69-73. doi: 10.1016/j.cois.2016.07.004

Breed, G. A., Stichter, S., and Crone, E. E. (2013). Climate-driven changes in northeastern US butterfly communities. Nature Clim. Change 3, 142-145. doi: $10.1038 /$ nclimate1663

Brennan, A. C., Woodward, G., Seehausen, O., Muñoz-Fuentes, V., Moritz, C., Guelmami, A., et al. (2015). Hybridization due to changing species distributions: adding problems or solutions to conservation of biodiversity during global change? Evol. Ecol. Res. 16, 475-491. Available online at: http:// evolutionary-ecology.com/abstracts/v16/2905.html

Britch, S. C., Cain, M. L., and Howard, D. J. (2001). Spatio-temporal dynamics of the Allonemobius fasciatus- A. socius mosaic hybrid zone: a 14-year perspective. Mol. Ecol. 10, 627-638. doi: 10.1046/j.1365-294x.2001.01215.x

Buckley, L. B., Nufio, C. R., Kirk, E. M., and Kingsolver, J. G. (2015). Elevational differences in developmental plasticity determine phenological responses of grasshoppers to recent climate warming. Proc. Biol. Sci. 282, 20150441-20150446. doi: 10.1098/rspb.2015.0441

Buggs, R. J. A. (2007). Empirical study of hybrid zone movement. Heredity 99, 301-312. doi: 10.1038/sj.hdy.6800997

Burban, C., Gautier, M., Leblois, R., Landes, J., Santos, H., Paiva, M.R., et al. (2016). Evidence for low-level hybridization between two allochronic populations of the pine processionary moth, Thaumetopoea pityocampa (Lepidoptera: Notodontidae). Biol. J. Linn. Soc. 119, 311-328. doi: 10.1111/bij.12829

Bush, G. L. (1969). Sympatric host race formation and speciation in frugivorous flies of the genus Rhagoletis (Diptera, Tephritidae). Evolution 23, 237-251. doi: 10.1111/j.1558-5646.1969.tb03508.x

Canestrelli, D., Porretta, D., Lowe, W. H., Bisconti, R., Carere, C., and Nascetti, G. (2016). The tangled evolutionary legacies of range expansion and hybridization. Trends Ecol. Evol. 31, 677-688. doi: 10.1016/j.tree.2016.06.010

Cohen, J. M., Lajeunesse, M. J., and Rohr, J. R. (2018). A global synthesis of animal phenological responses to climate change. Nature Clim. Change 8, 1-8. doi: 10.1038/s41558-018-0067-3

Conrad, T., Stöcker, C., and Ayasse, M. (2017). The effect of temperature on male mating signals and female choice in the red mason bee, Osmia bicornis (L.). Ecol. Evol. 7, 8966-8975. doi: 10.1002/ece3.3331

Cooley, J. R., Simon, C., Marshall, D. C., Slon, K., and Ehrhardt, C. (2001). Allochronic speciation, secondary contact, and reproductive character displacement in periodical cicadas (Hemiptera: Magicicada spp.): genetic, morphological, and behavioural evidence. Mol. Ecol. 10, 661-671. doi: 10.1046/j.1365-294x.2001.01210.x

Crozier, L., and Dwyer, G. (2006). Combining population-dynamic and ecophysiological models to predict climate-induced insect range shifts. Am. Nat. 167, 853-866. doi: 10.1086/504848

Dasmahapatra, K. K., Blum, M. J., Aiello, A., Hackwel, S., Davies, N., Bermingham, E. P., et al. (2002). Inferences from a rapidly moving hybrid zone. Evolution 56, 741-753. doi: 10.1111/j.0014-3820.2002.tb01385.x
Dell, A. I., Pawar, S., and Van Savage, M. (2011). Systematic variation in the temperature dependence of physiological and ecological traits. Proc. Natl. Acad. Sci. U.S.A. 108, 10591-10596. doi: 10.1073/pnas. 1015178108

Deutsch, C. A., Tewksbury, J. J., Huey, R. B., Sheldon, K. S., Ghalambor, C. K., Haak, D. C., et al. (2008). Impacts of climate warming on terrestrial ectotherms across latitude. Proc. Natl. Acad. Sci. U.S.A. 105, 6668-6672. doi: 10.1073/pnas.0709472105

Diamond, S. E., Frame, A. M., Martin, R. A., and Buckley, L. B. (2011). Species' traits predict phenological responses to climate change in butterflies. Ecology 92, 1005-1012. doi: 10.1890/10-1594.1

Dickinson, J. L., Shirk, J., Bonter, D., Bonney, R., Crain, R. L., Martin, J., et al. (2012). The current state of citizen science as a tool for ecological research and public engagement. Front. Ecol. Environ. 10, 291-297. doi: 10.1890/110236

Dingle, H., and Mousseau, T. A. (1994). Geographic variation in embryonic development time and stage of diapause in a grasshopper. Oecologia 97, 179-185. doi: 10.1007/BF00323147

Dingle, H., Mousseau, T. A., and Scott, S. M. (1990). Altitudinal variation in life cycle syndromes of California populations of the grasshopper, Melanoplus sanguinipes (F.). Oecologia 84, 199-206. doi: 10.1007/BF00318272

Dirzo, R., Young, H. S., Galetti, M., Ceballos, G., Isaac, N. J. B., and Collen, B. (2014). Defaunation in the Anthropocene. Science 345, 401-406. doi: $10.1126 /$ science. 1251817

Doherty, J., and Hoy, R. (1985). The auditory behavior of crickets: some views of genetic coupling, song recognition, and predator detection. Q. Rev. Biol. 60, 457-472. doi: $10.1086 / 414566$

Doherty, J. A. (1985). Temperature coupling and "trade-off" phenomena in the acoustic communication system of the cricket, Gryllus bimaculatus De Geer (Gryllidae). J. Exp. Biol. 114, 17-35.

Dolbear, A. (1897). The cricket as a thermometer. Am. Nat. 31, 970-971. doi: $10.1086 / 276739$

Dopman, E. B. (2011). Genetic hitchhiking associated with life history divergence and colonization of North America in the European corn borer moth. Genetica 139, 565-573. doi: 10.1007/s10709-010-9514-4

Dopman, E. B., Robbins, P. S., and Seaman, A. (2010). Components of reproductive isolation between North American pheromone strains of the European corn borer. Evolution 64, 881-902. doi: 10.1111/j.1558-5646.2009.00883.x

Edmunds, L. JR (1963). The relation between temperature and flashing intervals in adult male fireflies, Photinus pyralis. Ann. Entomol. Soc. Am. 56, 716-718. doi: 10.1093/aesa/56.5.716

Endler, J. A. (1977). Geographic Variation, Speciation, and Clines. Princeton, NJ: Princeton University Press.

Feder, J. L., Berlocher, S. H., Roethele, J. B., Dambroski, H., Smith, J. J., Perry, W. L., et al. (2003). Allopatric genetic origins for sympatric host-plant shifts and race formation in Rhagoletis. Proc. Natl. Acad. Sci. U.S.A. 100, 10314-10319. doi: $10.1073 /$ pnas. 1730757100

Feder, J. L., and Filchak, K. E. (1999). It's about time: the evidence for host plant-mediated selection in the apple maggot fly, Rhagoletis pomonella, and its implications for fitness trade-offs in phytophagous insects. Entomol. Exp. Appl. 91, 211-225. doi: 10.1046/j.1570-7458.1999.00486.x

Feder, J. L., Xie, X., Rull, J., Velez, S., Forbes, A., Leung, B., et al. (2005). Mayr, Dobzhansky, and Bush and the complexities of sympatric speciation in Rhagoletis. Proc. Natl. Acad. Sci. U.S.A. 102, 6573-6580. doi: 10.1073/pnas.0502099102

Fedorka, K. M., Winterhalter, W. E., Shaw, K. L., Brogan, W. R., and Mousseau, T. A. (2012). The role of gene flow asymmetry along an environmental gradient in constraining local adaptation and range expansion. J. Evol. Biol. 25, 1676-1685. doi: $10.1111 / j .1420-9101.2012 .02552 . x$

Filchak, K. E., Roethele, J. B., and Feder, J. L. (2000). Natural selection and sympatric divergence in the apple maggot Rhagoletis pomonella. Nature 407, 739-742. doi: $10.1038 / 35037578$

Fitzpatrick, M. J., and Gray, D. A. (2001). Divergence between the courtship songs of the field crickets Gryllus texensis and Gryllus rubens (Orthoptera, Gryllidae). Ethology 107, 1075-1085. doi: 10.1046/j.1439-0310.2001.00730.x

Forbes, A. A., Devine, S. N., Hippee, A. C., Tvedte, E. S., Ward, A. K. G., Widmayer, H. A., et al. (2017). Revisiting the particular role of host shifts in initiating insect speciation. Evolution 71, 1126-1137. doi: 10.1111/evo.13164

Gabel, E., Gray, D. A., and Hennig, R. M. (2016). How females of chirping and trilling field crickets integrate the 'what' and 'where' of male 
acoustic signals during decision making. J. Comp. Physiol. A 202, 823-837. doi: 10.1007/s00359-016-1124-x

Gibert, J. P., Chelini, M.-C., Rosenthal, M. F., and DeLong, J. P. (2016). Crossing regimes of temperature dependence in animal movement. Glob. Change Biol. 22, 1722-1736. doi: $10.1111 / \mathrm{gcb} .13245$

Godefroid, M., Rocha, S., Santos, H., Paiva, M. R., Burban, C., Kerdelhué, C., et al. (2016). Climate constrains range expansion of an allochronic population of the pine processionary moth. Diversity Distrib. 22, 1288-1300. doi: 10.1111/ddi.12494

Gompert, Z., Mandeville, E. G., and Buerkle, C. A. (2017). Analysis of population genomic data from hybrid zones. Annu. Rev. Ecol. Evol. Syst. 48, 207-229. doi: 10.1146/annurev-ecolsys-110316-022652

Grabenstein, K. C., and Taylor, S. A. (2018). Breaking barriers: causes, consequences, and experimental utility of human-mediated hybridization. Trends Ecol. Evol. 33, 198-212. doi: 10.1016/j.tree.2017.12.008

Grace, J. L., and Shaw, K. L. (2004). Effects of developmental environmental environment on signal-preference coupling in a Hawaiian cricket. Evolution 58, 1627-1633. doi: 10.1111/j.0014-3820.2004.tb01744.x

Gray, D. A., Gutierrez, N. J., and Chen, T. L. (2016). Species divergence in field crickets: genetics, song, ecomorphology, and pre-and postzygotic isolation. Biol. J. Linn. Soc. 117, 192-205. doi: 10.1111/bij.12668

Greenfield, M. D., and Medlock, C. (2007). Temperature coupling as an emergent property: parallel thermal effects on male song and female response do not contribute to species recognition in an acoustic moth. Evolution 61, 1590-1599. doi: $10.1111 /$ j.1558-5646.2007.00140.x

Habel, J. C., Samways, M. J., and Schmitt, T. (2019). Mitigating the precipitous decline of terrestrial European insects: requirements for a new strategy. Biodiversity Conserv. 28, 1-18. doi: 10.1007/s10531-019-01741-8

Harrison, R. G. (1985). Barriers to gene exchange between closely related cricket species. II. Life cycle variation and temporal isolation. Evolution 39, 244-259. doi: 10.1111/j.1558-5646.1985.tb05664.x

Harrison, R. G. (1986). Pattern and process in a narrow hybrid zone. Heredity 56, 337-349. doi: 10.1038/hdy.1986.55

Harrison, R. G. (1990). Hybrid zones: windows on evolutionary process. Oxford Surveys Evol. Biol. 7, 69-128.

Harrison, R. G., and Larson, E. L. (2014). Hybridization, introgression, and the nature of species boundaries. J. Hered. 105, 795-809. doi: 10.1093/jhered/esu033

Hellmann, J. J., Pelini, S. L., Prior, K. M., and Dzurisin, J. D. K. (2008). The response of two butterfly species to climatic variation at the edge of their range and the implications for poleward range shifts. Oecologia 157, 583-592. doi: $10.1007 / \mathrm{s} 00442-008-1112-0$

Hennig, R. M., Blankers, T., and Gray, D. A. (2016). Divergence in male cricket song and female preference functions in three allopatric sister species. J. Comp. Physiol. A 202, 347-360. doi: 10.1007/s00359-016-1083-2

Hewitt, G. M. (1988). Hybrid zones-natural laboratories for evolutionary studies. Trends Ecol. Evol. 3, 158-167. doi: 10.1016/0169-5347(88)90033-X

Hewitt, G. M. (2011). Quaternary phylogeography: the roots of hybrid zones. Genetica 139, 617-638. doi: 10.1007/s10709-011-9547-3

Holmes, M. W., Hammond, T. T., Wogan, G. O. U., Walsh, R. E., LaBarbera, K., Wommack, E. A., et al. (2016). Natural history collections as windows on evolutionary processes. Mol. Ecol. 25, 864-881. doi: 10.1111/mec.13529

Howard, D. J. (1986). A zone of overlap and hybridization between two ground cricket species. Evolution 40, 34-43. doi: 10.1111/j.1558-5646.1986.tb 05715.x

Howard, D. J., and Waring, G. L. (1991). Topographic diversity, zone width, and the strength of reproductive isolation in a zone of overlap and hybridization. Evolution 45, 1120-1135. doi: 10.1111/j.1558-5646.1991.tb04379.x

Jamieson, M. A., Trowbridge, A. M., Raffa, K. F., and Lindroth, R. L. (2012). Consequences of climate warming and altered precipitation patterns for plant-insect and multitrophic interactions. Plant Physiol. 160, 1719-1727. doi: 10.1104/pp.112.206524

Jang, Y., and Gerhardt, H. C. (2006). Divergence in the calling songs between sympatric and allopatric populations of the southern wood cricket Gryllus fultoni (Orthoptera: Gryllidae). J. Evol. Biol. 19, 459-472. doi: $10.1111 / j .1420-9101.2005 .01014 . x$

Janzen, D. H. (1967). Why mountain passes are higher in the tropics? Am. Nat. 101, 233-249. doi: 10.1086/282487
Jones, M. R., and Good, J. M. (2015). Targeted capture in evolutionary and ecological genomics. Mol. Ecol. 25, 185-202. doi: 10.1111/mec.13304

Kharouba, H. M., Lewthwaite, J. M. M., Guralnick, R., Kerr, J. T., and Vellend, M. (2019). Using insect natural history collections to study global change impacts: challenges and opportunities. Phil. Trans. R. Soc. B 374, 20170405-20170410. doi: $10.1098 /$ rstb.2017.0405

Kindle, T. K., Johnson, K. M., Ivy, T. M., Weddle, C. B., and Sakaluk, S. K. (2006), Female mating frequency increases with temperature in two cricket species, Gryllodes sigillatus and Acheta domesticus (Orthoptera: Gryllidae). Can. J. Zool. 84, 1345-1350. doi: 10.1139/z06-127

Kivelä, S. M., Välimäki, P., Carrasco, D., Mäenpää, M. I., and Oksanen, J. (2011). Latitudinal insect body size clines revisited: a critical evaluation of the saw-tooth model. J. Anim. Ecol. 80, 1184-1195. doi: 10.1111/j.1365-2656.2011.01864.x

Koyama, T., Ito, H., Fujisawa, T., Ikeda, H., Kakishima, S., Cooley, J. R., et al. (2016). Genomic divergence and lack of introgressive hybridization between two 13-year periodical cicadas support life cycle switching in the face of climate change. Mol. Ecol. 25, 5543-5556. doi: 10.1111/mec.13858

Kozak, G. M., Wadsworth, C. B., Kahne, S. C., Bogdanowicz, S. M., Harrison, R. G., Coates, B. S., et al. (2017). A combination of sexual and ecological divergence contributes to rearrangement spread during initial stages of speciation. Mol. Ecol. 26, 2331-2347. doi: 10.1111/mec.14036

Larson, E. L., Guilherme Becker, C., Bondra, E. R., and Harrison, R. G. (2013). Structure of a mosaic hybrid zone between the field crickets Gryllus firmus and G. pennsylvanicus. Ecol. Evol. 3, 985-1002. doi: 10.1002/ece3.514

Larson, E. L., White, T. A., Ross, C. L., and Harrison, R. G. (2014). Gene flow and the maintenance of species boundaries. Mol. Ecol. 23, 1668-1678. doi: $10.1111 / \mathrm{mec} .12601$

Leblois, R., Gautier, M., Rohfritsch, A., Foucaud, J., Burban, C., Galan, M., et al. (2017). Deciphering the demographic history of allochronic differentiation in the pine processionary moth Thaumetopoea pityocampa. Mol. Ecol. 27, 264-278. doi: 10.1111/mec.14411

Levy, R. C., Kozak, G. M., Wadsworth, C. B., Coates, B. S., and Dopman, E. B. (2014). Explaining the sawtooth: latitudinal periodicity in a circadian gene correlates with shifts in generation number. J. Evol. Biol. 28, 40-53. doi: $10.1111 /$ jeb.12562

Mallet, J., Wynne, I. R., and Thomas, C. D. (2010). Hybridisation and climate change: brown argus butterflies in Britain (Polyommatus subgenus Aricia). Insect Conserv. Divers. 4, 192-199. doi: 10.1111/j.1752-4598.2010.00122.x

Mandeville, E. G., Parchman, T. L., McDonald, D. B., and Buerkle, C. A. (2015). Highly variable reproductive isolation among pairs of Catostomus species. Mol. Ecol. 24, 1856-1872. doi: $10.1111 / \mathrm{mec} .13118$

Mandeville, E. G., Parchman, T. L., Thompson, K. G., Compton, R. I., Gelwicks, K. R., Song, S. J., et al. (2017). Inconsistent reproductive isolation revealed by interactions between Catostomus fish species. Evol. Lett. 1, 255-268. doi: $10.1002 / \mathrm{evl} 3.29$

Maroja, L. S., McKenzie, Z. M., Hart, E., Jing, J., Larson, E. L., and Richardson, D. P. (2014). Barriers to gene exchange in hybridizing field crickets: the role of male courtship effort and cuticular hydrocarbons. BMC Evol. Biol. 14, 65. doi: 10.1186/1471-2148-14-65

Marshall, D. C., and Cooley, J. R. (2000). Reproductive character displacement and speciation in periodical cicadas, with description of a new species, 13-year Magicicada neotredecim. Evolution 54, 1313-1325. doi: 10.1111/j.0014-3820.2000.tb00564.x

Masaki, S. (1961). Geographic variation of diapause in insects. Bull. Fac. Agric. Hirosaki Univ. 7, 66-98.

Masaki, S. (1967). Geographic variation and climatic adaptation in a field cricket (Orthoptera: Gryllidae). Evolution 21, 725. doi: 10.1111/j.1558-5646.1967.tb03430.x

Masaki, S. (1978a). Climatic adaptation and species status in the lawn ground cricket II. Body size. Oecologia 35, 343-356. doi: 10.1007/BF00345141

Masaki, S. (1978b). "Seasonal and latitudinal adaptations in the life cycles of crickets," in Evolution of Insect Migration and Diapause, ed H. Dingle (New York, NY: Springer), 72-100.

Masaki, S. (1983). Climatic speciation in Japanese ground crickets. GeoJournal 7, 483-490. doi: 10.1007/BF00218520

Mattsson, M., Hood, G. R., Feder, J. L., and Ruedas, L. A. (2015). Rapid and repeatable shifts in life-history timing of Rhagoletis pomonella (Diptera: 
Tephritidae) following colonization of novel host plants in the Pacific Northwestern United States. Ecol. Evol. 5, 5823-5837. doi: 10.1002/ece3.1826

Maurer, J. A., Shepard, J. H., Crabo, L. G., Hammond, P. C., Zack, R. S., and Peterson, M. A. (2018). Phenological responses of 215 moth species to interannual climate variation in the Pacific Northwest from 1895 through 2013. PLOS ONE 13:e0202850. doi: 10.1371/journal.pone.0202850

Mendelson, T. C., and Shaw, K. L. (2002). Genetic and behavioral components of the cryptic species boundary between Laupala cerasina and L. kohalensis (Orthoptera: Gryllidae). Genetica 116, 301-310. doi: 10.1023/A:1021244812270

Mendelson, T. C., and Shaw, K. L. (2005). Sexual behaviour: rapid speciation in an arthropod. Nature 433, 375-376. doi: 10.1038/433375a

Menéndez, R., González-Megías, A., Jay-Robert, P., and Marquéz-Ferrando, R. (2013). Climate change and elevational range shifts: evidence from dung beetles in two European mountain ranges. Glob. Ecol. Biogeogr. 23, 646-657. doi: 10.1111 /geb.12142

Merrill, R. M., Gutiérrez, D., Lewis, O. T., Gutiérrez, J., Díez, S. B., and Wilson, R. J. (2008). Combined effects of climate and biotic interactions on the elevational range of a phytophagous insect. J. Anim. Ecol. 77, 145-155. doi: 10.1111/j.1365-2656.2007.01303.x

Mousseau, T. A. (1997). Ectotherms follow the converse to Bergmann's rule. Evolution 51:630. doi: 10.1111/j.1558-5646.1997.tb02453.x

Narins, P. M., and Meenderink, S. W. F. (2014). Climate change and frog calls: long-term correlations along a tropical altitudinal gradient. Proc. Biol. Sci. 281:20140401. doi: 10.1098/rspb.2014.0401

Nufio, C. R., McGuire, C. R., Bowers, M. D., and Guralnick, R. P. (2010). Grasshopper community response to climatic change: variation along an elevational gradient. PLoS ONE 5:e12977. doi: 10.1371/journal.pone.0012977

Ording, G. J., Mercader, R. J., Aardema, M. L., and Scriber, J. M. (2010). Allochronic isolation and incipient hybrid speciation in tiger swallowtail butterflies. Oecologia 162, 523-531. doi: 10.1007/s00442-009-1493-8

Orr, M. R. (1996). Life-history adaptation and reproduction isolation in a grasshopper hybrid zone. Evolution 50, 704-716. doi: 10.1111/j.1558-5646.1996.tb03880.x

Otte, D. (1992). Evolution of cricket songs. J. Orthoptera Res. 1, 25-49. doi: $10.2307 / 3503559$

Parmesan, C. (2006). Ecological and evolutionary responses to recent climate change. Аnпu. Rev. Ecol. Evol. Syst. 37, 637-669. doi: 10.1146/annurev.ecolsys.37.091305.110100

Parmesan, C., Ryrholm, N., Stefanescu, C., Hill, J. K., Thomas, C. D., Descimon, H., et al. (1999). Poleward shifts in geographical ranges of butterfly species associated with regional warming. Nature 399, 579-583. doi: 10.1038/21181

Parsons, S. M. A., and Joern, A. (2013). Life history traits associated with body size covary along a latitudinal gradient in a generalist grasshopper. Oecologia 174, 379-391. doi: 10.1007/s00442-013-2785-6

Pearse, W. D., Davis, C. C., Inouye, D. W., Primack, R. B., and Davies, T. J. (2017). A statistical estimator for determining the limits of contemporary and historic phenology. Nat. Ecol. Evol. 1, 1876-1882. doi: 10.1038/s41559-017-0350-0

Pickford, R. (1953). A two-year life-cycle in grasshoppers (Orthoptera: Acrididae) overwintering as eggs and nymphs. Can. Entomol. 85, 9-14. doi: 10.4039/Ent859-1

Pimentel, C., Calvão, T., Santos, M., Ferreira, C., Neves, M., and Nilsson, J. A. (2006). Establishment and expansion of a Thaumetopoea pityocampa (Den. \& Schiff.) (Lep. Notodontidae) population with a shifted life cycle in a production pine forest, Central-Coastal Portugal. Forest Ecol. Manag. 233, 108-115. doi: 10.1016/j.foreco.2006.06.005

Pires, A., and Hoy, R. R. (1992). Temperature coupling in cricket acoustic communication. J. Comp. Physiol. A 171, 79-92. doi: 10.1007/BF00195963

Prudic, K., McFarland, K., Oliver, J., Hutchinson, R., Long, E., Kerr, J., et al. (2017). eButterfly: leveraging massive online citizen science for butterfly conservation. Insects 8, 53-12. doi: 10.3390/insects8020053

Ragland, G. J., Sim, S. B., Goudarzi, S., Feder, J. L., and Hahn, D. A. (2012). Environmental interactions during host race formation: host fruit environment moderates a seasonal shift in phenology in host races of Rhagoletis pomonella. Funct. Ecol. 26, 921-931. doi: 10.1111/j.1365-2435.2012.0 1992.x

Ritchie, M. G., Saarikettu, M., Livingstone, S., and Hoikkala, A. (2001). Characterization of female preference functions for Drosophila montana courtship song and a test of the temperature coupling hypothesis. Evolution 55, 721-727. doi: 10.1554/0014-3820(2001)055[0721:COFPFF]2.0.CO;2

Rodríguez, R. L., Hallett, A. C., Kilmer, J. T., and Fowler-Finn, K. D. (2012). Curves as traits: genetic and environmental variation in mate preference functions. J. Evol. Biol. 26, 434-442. doi: 10.1111/jeb.12061

Rosenthal, G. G. (2017). Mate Choice: The Evolution of Sexual Decision Making From Microbes to Humans. Princeton, NJ: Princeton University Press.

Rowe, K. C., Rowe, K. M. C., Tingley, M. W., Koo, M. S., Patton, J. L., Conroy, C. J., et al. (2014). Spatially heterogeneous impact of climate change on small mammals of montane California. Proc. Biol. Sci. 282:20141857. doi: $10.1098 /$ rspb.2014.1857

Ryan, S. F., Deines, J. M., Scriber, J. M., Pfrender, M. E., Jones, S. E., Emrich, S. J., et al. (2018). Climate-mediated hybrid zone movement revealed with genomics, museum collection, and simulation modeling. Proc. Natl. Acad. Sci. U.S.A. 16:201714950. doi: $10.1073 /$ pnas.1714950115

Sánchez-Bayo, F., and Wyckhuys, K. A. G. (2019). Worldwide decline of the entomofauna: a review of its drivers. Biol. Conserv. 232, 8-27. doi: 10.1016/j.biocon.2019.01.020

Santos, H., Burban, C., Rousselet, J., Rossi, J. P., Branco, M., and Kerdelhu,é, C. (2011). Incipient allochronic speciation in the pine processionary moth (Thaumetopoea pityocampa, Lepidoptera, Notodontidae). J. Evol. Biol. 24, 146-158. doi: 10.1111/j.1420-9101.2010.02147.x

Santos, H., Rousselet, J., Magnoux, E., Paiva, M.-R., Branco, M., and Kerdelhué, C. (2007). Genetic isolation through time: allochronic differentiation of a phenologically atypical population of the pine processionary moth. Proc. Biol. Sci. 274, 935-941. doi: 10.1098/rspb.2006.3767

Scriber, J., Elliot, B., Maher, E., McGuire, M., and Niblack, M. (2014). Adaptations to "thermal time" constraints in Papilio: latitudinal and local size clines differ in response to regional climate change. Insects 5, 199-226. doi: 10.3390/insects5010199

Scriber, J. M. (2011). Impacts of climate warming on hybrid zone movement: Geographically diffuse and biologically porous "species borders." Insect Sci. 18, 121-159. doi: 10.1111/j.1744-7917.2010.01367.x

Senner, N. R., Stager, M., and Cheviron, Z. (2017). Spatial and temporal heterogeneity in climate change limits species' dispersal capabilities and adaptive potential. Ecography 41, 1428-1440. doi: 10.1111/ecog. 03234

Silvertown, J. (2009). A new dawn for citizen science. Trends Ecol. Evol. 24, 467-471. doi: 10.1016/j.tree.2009.03.017

Simon, C., Tang, J., Dalwadi, S., Staley, G., Deniega, J., and Unnasch, T. R. (2000). Genetic evidence for assortative mating between 13 -year cicadas and sympatric "17-year cicadas with 13-year life cycles" provides support for allochronic speciation. Evolution 54, 1326-1336. doi: 10.1111/j.0014-3820.2000.tb0 0565.x

Sota, T., Yamamoto, S., Cooley, J. R., Hill, K. B. R., Simon, C., and Yoshimura, J. (2013). Independent divergence of 13- and 17-y life cycles among three periodical cicada lineages. Proc. Natl. Acad. Sci. U.S.A. 110, 6919-6924. doi: 10.1073/pnas.1220060110

Sparks, T. H., Dennis, R. L. H., Croxton, P. J., and Cade, M. (2007). Increased migration of Lepidoptera linked to climate change. Eur. J. Entomol. 104, 139-143. doi: 10.14411/eje.2007.019

Sullivan, B. L., Wood, C. L., Iliff, M. J., Bonney, R. E., Fink, D., and Kelling, S. (2009). eBird: A citizen-based bird observation network in the biological sciences. Biol. Conserv. 142, 2282-2292. doi: 10.1016/j.biocon.2009. 05.006

Tanaka, S. (1991). Genetic compatibility and geographic profile of two closely related species of Allonemobius (Gryllidae: Orthoptera). Ann. Entomol. Soc. Am. 84, 29-36. doi: 10.1093/aesa/84.1.29

Tauber, C. A., and Tauber, M. J. (1981). Insect seasonal cycles: genetics and evolution. Annu. Rev. Ecol. Syst. 12, 281-308. doi: 10.1146/annurev.es.12.110181.001433

Taylor, R. S., and Friesen, V. L. (2017). The role of allochrony in speciation. Mol. Ecol. 26, 3330-3342. doi: 10.1111/mec.14126

Taylor, S. A., Larson, E. L., and Harrison, R. G. (2015). Hybrid zones: windows on climate change. Trends Ecol. Evol. 30, 398-406. doi: 10.1016/j.tree.2015.04.010

Tobin, P. C., Nagarkatti, S., Loeb, G., and Saunders, M. C. (2008). Historical and projected interactions between climate change and insect 
voltinism in a multivoltine species. Glob. Change Biol. 14, 951-957. doi: 10.1111/j.1365-2486.2008.01561.x

Walker, S. E., and Cade, W. H. (2003). The effects of temperature and age on calling song in a field cricket with a complex calling song, Teleogryllus oceanicus (Orthoptera: Gryllidae). Can. J. Zool. 81, 1414-1420. doi: 10.1139/z03-106

Walker, T. J. (1962). Factors responsible for intraspecific variation in the calling songs of crickets. Evolution 16, 407-428. doi: 10.1111/j.1558-5646.1962.tb03234.x

Wellenreuther, M., Tynkkynen, K., and Svensson, E. I. (2010). Simulating range expansion: male species recognition and loss of premating isolation in damselflies. Evolution 64, 242-252. doi: 10.1111/j.1558-5646.2009.00815.x

Wiens, J. J. (2016). Climate-related local extinctions are already widespread among plant and animal species. PLoS Biol. 14:e2001104. doi: 10.1371/journal.pbio.2001104

Xie, X., Michel, A. P., Schwarz, D., Rull, J., Velez, S., Forbes, A. A., et al. (2008). Radiation and divergence in the Rhagoletis Pomonella species complex: inferences from DNA sequence data. J. Evol. Biol. 21, 900-913. doi: 10.1111/j.1420-9101.2008.01507.x
Yamamoto, S., and Sota, T. (2009). Incipient allochronic speciation by climatic disruption of the reproductive period. Proc. Biol. Sci. 276, 2711-2719. doi: $10.1098 / \mathrm{rspb} .2009 .0349$

Yamamoto, S., and Sota, T. (2012). Parallel allochronic divergence in a winter moth due to disruption of reproductive period by winter harshness. Mol. Ecol. 21, 174-183. doi: 10.1111/j.1365-294X.2011.05371.x

Conflict of Interest Statement: The authors declare that the research was conducted in the absence of any commercial or financial relationships that could be construed as a potential conflict of interest.

Copyright (c) 2019 Larson, Tinghitella and Taylor. This is an open-access article distributed under the terms of the Creative Commons Attribution License (CC BY). The use, distribution or reproduction in other forums is permitted, provided the original author(s) and the copyright owner(s) are credited and that the original publication in this journal is cited, in accordance with accepted academic practice. No use, distribution or reproduction is permitted which does not comply with these terms. 